\title{
Propostes alternatives per a l'avaluació de la recerca en ciències socials
}

\author{
J oan C als (professor del D epartament d'Economia A plicada de la UAB) \\ $M$ iquel D omènech (professor del D epartament de Psicologia de la Salut i Psicologia \\ Social de laUAB) \\ Joan G ómez (professor del $D$ epartament de Ciències de l'Antiguitat i de l'E dat M itjana de \\ la $\cup A B$ )
}

\section{Joan Cals}

La meva intervenció en aquestes jornades se centrarà en l'exposició i el comentari d'una resolució que el D epartament d'Economia Aplicada va aprovar el juliol de 1999, per participar en el tràmit d'informació pública del projecte d'avaluació de la recerca preparat per la U AB. Tracta sobre la classificació de revistes d'economia del CO N ACIT, perquè enteníem que era la columna vertebral de l'avaluació, tot i que el projecte de la nostra universitat preveia la utilització d'aquesta classificació dins una gamma àmplia d'altres mèrits. I hem de tenir present que les virtuts i els defectes - que són molts i importants- d'aquesta classificació poden influir, a mitjà termini, de manera decisiva no solament en l'avaluació de la recerca col·lectiva - la dels departaments i les universitats, per condicionarne els pressupostos via contractes programa- , sinó també en la de la recerca individual - trams de recerca - i en la selecció del professorat universitari. Les seves conseqüències en aquest darrer aspecte han de ser examinades des de la perspectiva del que comportarien per a la docència - tipus i mètodes- en una ciència social com ara l'Economia. Si, com he sentit, els defectes de l'esmentada classificació no són exclusius de l'àrea que jo conec, ens trobaríem davant d'una iniciativa que, partint d'uns lloables objectius de control i qualitat, comportaria el risc de biaixos preocupants en la universitat del futur.

$\mathrm{H}$ aig d'advertir, de bell antuvi, que les meves consideracions i els meus judicis són els que corresponen a un professor universitari que creu en la necessitat i en l'exigencia moral de l'avaluació de tota la seva activitat, la investigadora, però també la docent i, en conjunt, la seva aportació a la institució i a la societat.

La resolució del D epartament d'Economia Aplicada que exposaré ara, va ser aprovada pràcticament per unanimitat en un col·lectiu on hi ha neoclàssics, keynessians, postkeynessians, marxistes, institucionalistes, etc.; hi som gairebé tots en aquest departament. I és eloqüent que en un col·lectiu tan divers la classificació de revistes d'economia del CO N ACIT provoqués un rebuig generalitzat. En un treball meu de començaments del 2000, fet amb una mostra de revistes i camps d'especialització, vaig documentar una part de les deficiències que la resolució assenyalava. 
El primer punt de la resolució deia que la classificació en economia contenia una gran quantitat d'errors, omissions i incoherències en relació amb els propis criteris generals de definició dels nivells de les revistes establerts pel CON ACIT. Podem parlar d'un mínim de vint-i-dos errors molt notoris, incoherències 0 , senzillament, revistes de primera línia (angleses, americanes, britàniques, espanyoles...) que no hi figuraven. En una perspectiva més àmplia, la Ilista de les omissions es fa llarga. La classificació del CO N ACIT recull 450 títols. D oncs bé, atès que en el seu nivell $D$, de fet, és purament el criteri residual el que ha marcat la inclusió de les revistes, és inexplicable que el conjunt de la classificació sumi només aquest total, quan en la rúbrica «Economia» del catàleg col-lectiu de les universitats catalanes - que, lògicament, no és exhaustiu - s'hi apleguen 554 referències i a Econlit - que conté, solament, 13 revistes espanyoles- les referències pugen fins a 645 . No és que jo propugni la inclusió a la classificació de totes les revistes existents. Em limito a aportar un contrast de dades.

En un segon punt afirmàvem que la classificació en economia tendeix a ignorar 0 , en el millor dels casos, a situar en el nivell $D$, què és l'últim, revistes que acrediten un bon nivell de qual itat i una avaluació rigorosa dels originals, però que tenen la particularitat d'estar dedicades a àmbits temàtics especialitzats i/o escrites en llengua no anglesa. Això vulnera els criteris classificatoris emprats pel CON ACIT, un dels quals assigna al nivell C les revistes de «bon nivell de qualitat dins el seu àmbit, amb un sistema d'avaluació d'originals rigorós». Per tant, l'especialització econòmica en una sèrie d'àmbits - que hem pogut documentar, com a mínim, per a educació, treball, planejament i habitatge, transport i turisme- està clarament discriminada de manera negativa, mentre que el fet d'estar escrites en llengua no anglesa afecta revistes rellevants de treball, economía política, desenvolupament, economia d'Espanya i de països, economía industrial, política econòmica i economia regional i urbana.

La qüestió de la llengua mereix un comentari a part. La classificació en economia no conté, en els nivells A ( 22 títols) ni B (92 títols), cap revista que no estigui escrita en anglès. En el $C$ ( 247 títols), les úniques excepcions a aquesta norma són 4 revistes en alemany i 6 en castellà. Amb aquestes dades, salta a la vista que se n'exclouen nombroses revistes a través de les quals es publica una part substancial de la recerca econòmica aplicada de més rellevància i impacte social a diversos països, començant pel nostre. I és de domini comú que els millors i més precisos treballs sobre les nostres qüestions econòmiques - conjuntura, fets, anàlisis sectorials, polítiques- no es troben, generalment, escrits en anglès, sinó en castellà o català.

En un tercer punt, assenyalàvem que la classificació de revistes en economia exclou sistemàticament les que són pluridisciplinàries, amb la qual cosa es diferencia de la pràctica en altres àrees. $\mathrm{H}$ e vist, per exemple, una fórmula interessant aplicada a geografia, que recull «revistes que no són de geografia però en les quals els geògrafs publiquen freqüentment». C rec que no és una orientació acceptable excloure, per norma, els treballs de recerca que se situen en terrenys de frontera amb altres disciplines. 
Finalment, la resolució del D epartament d'Economia A plicada observava que l'últim nivell de la classificació, el $D$, era d'una gran heterogeneïtat i no permetia observar la utilització d'uns criteris clars, ja que el resultat era una barreja de revistes amb nivells de rigor, prestigi i qualitat molt desiguals. EI defecte en qüestió és encara més greu quan s'observa que, d'acord amb els criteris del CO N ACIT, les revistes classificades com a D no haurien de ser puntuades. És cert que la U AB els atorga una petita valoració, però el tema que estem discutint va molt més enllà dels límits de la nostra universitat. Al nivell D hi han anat a parar bones revistes pel simple fet de la llengua en què estan escrites. Són nombrosos els economistes espanyols i catalans autors de la investigació més rellevant sobre la nostra realitat que tenen pràcticament tota la seva obra en revistes $D$, és a dir, és gent amb mèrits de recerca insignificants, segons el parer del CONACIT.

Els defectes exposats ens portaven a considerar que la classificació de revistes en economia quedava invalidada per ser emprada en l'avaluació de la recerca i no shavia d'utilitzar, perquè no és cert que qual sevol avaluació sigui sempre preferible a la no avaluació, i encara més si resulta que, amb els mateixos criteris, es pot arribar, sense grans esforços, a una llista substancialment millorada.

També afirmàvem que l'acumulació d'aquesta considerable sèrie de defectes discriminava obertament contra una recerca aplicada en economia que té gruix i podia perjudicar de manera greu un treball investigador de gran impacte directe sobre el progrés econòmic i el benestar social.

L'amplitud i dimensió del problema de la classificació de revistes en economia es fa evident en les dues etapes del procés. Primera, en la definició dels criteris i, segona, en l'aplicació. La definició dels criteris resol malament el tractament de la recerca aplicada enfront de la bàsica. Crec que no és un problema, només, de l'economia. El veig, igualment, en altres ciències socials. Ara bé, l'elecció d'uns criteris no prou ponderats, en economia - a diferència d'altres camps- sagreuja considerablement per causa d'una aplicació negligent que, als seus molts errors, hi suma la renúncia a corregir amb sensatesa els excessos del formalisme.

M oltes gràcies per la vostra atenció. 


\section{Miquel D omènech}

Jo el que volia era centrar el debat, ja no tant en els sistemes que sutilitzen per a l'avaluació, sinó sobre la pertinència mateixa de l'avaluació, si avaluar és una cosa que té sentit. Sobretot si ens preguntem què és el que s'avalua, quan es diu que s'avalua la recerca.

En principi, aparentment, un dels aspectes que s'avaluarien seria la qualitat que no és el treball. Aleshores, una de les primeres consideracions que crec que són evidents, és que l'indicador que sututilitza per avaluar la qualitat no és, aparentment, correcte. Perquè la qualitat en principi hauria de venir del contingut de la recerca, del contingut publicat a l'article, però no del lloc on es publica, perquè això no garanteix res.

$\mathrm{Hi}$ ha al gunes dades que són interessants, perquè a mi em sembla també que el debat cal situar-lo en un nivell molt, numèric, amb dades. No és una qüestió del que ens sembla o del que ens deixa de semblar. En un estudi publicat l'any 1990 sobre el C SIC , estem parlant d'una institució molt prestigiosa, probablement la més prestigiosa de l'Estat espanyol, on suposadament hi ha gent de molta qualitat i on tenen molts mitjans per fer recerca..., hi surten algunes dades que són bastant interessants, i que tindrien a veure amb el que seria l'indici fonamental de la qualitat que és la citació. En principi, un article podem entendre que és de qualitat si és molt citat. Suposadament, la comunitat de científics el llegeix i, si considera que és bo, l'utilitza.

Aquest estudi avalua articles entre l'any 1984 i l'any 1989. Resulta que els articles publicats el 1985 rebien una mitjana d'1,8 citacions per publicació. I els que s'havien publicat el 1986, perquè, clar, evidentment, com més anys fa que una recerca està publicada, més fàcil és que et citin, baixa fins a 1,1, fins al punt que, fent una comparació de tots, sortia que els articles rebien una mitjana de 0,4 citacions a l'any. Es a dir 0,4 citacions a l'any és el que el CSIC produeix. Això està publicat a $A R B O R$, una revista sobre ciència espanyola que ens diu quina és la mitjana de citacions... Clar, vist això, ara ningú no es pot enganyar que el que es mesura és la qual itat, perquè 0,4 citacions, segur que tots estaríem d'acord que és una xifra pèssima.

Això significa que hi ha moltíssimes publicacions que tenen 0 citacions. $\mathrm{Si}$, a més, tenim en compte que el $30 \%$ de les publicacions més citades són el resultat de col-laboracions amb centres estrangers, això vol dir que el que fa pujar aquesta mitjana, aquest $30 \%$, és que pràcticament un terç de les publicacions estan fetes amb centres estrangers que sabem que tenen més mitjans i per tant també tenen més possibilitats d'entrar a les revistes.

Per què això? Jo em dedico en part al que és la sociologia de la ciència, $i$ he entrevistat molts biòlegs, sobretot perquè és un camp que he treballat especialment, i és un camp en el qual Espanya està bé. Principalment a biologia molecular, es publiquen molts articles de persones reconegudes. Tinc un $\mathrm{col}$ - lega a qui he entrevistat, amb qui he treballat, que properament publicarà a $\mathrm{N}$ ature, que és molt important. És un bon investigador que publicarà a N ature un primer article i que des de fa molts anys que publica aquí, només 
en espanyol. D oncs bé, em comentava que a $\mathrm{N}$ ature o bé quan aquestes revistes reben articles que són signats només per espanyols, passen a la cua de les revisions. És una cosa que se sap. És a dir, la possibilitat que té un investigador a l'hora de publicar en revistes angleses és molt petita quan la seva llengua és el castellà.

Bé, i si es mesura, què mesurem? Si hi ha dubtes raonables per pensar que no mesurem la qualitat, què mesurem? Per entendre això crec que hauríem de fer una petita revisió de què implica publicar, és a dir, a quina mena de cicle ens veiem abocats quan ens posem a publicar. Si tenim en compte que, com aquest article d'ARBO R deia, el pressupost mínim d'un article del CSIC és d'un milió de pessetes, i la mitjana és de 3,5 milions per investigador i any, és ben palès que costa diners publicar. Per tant, una de les qüestions que queda clar que s'avalua és I'habilitat per aconseguir aquests diners.

Però, com busques els diners? No ho dic jo, ho diu Zimmerman, que és una de les més prestigioses figures de la filosfia de la ciència del context internacional. Aquesta persona diu: «La valoració per parts és una elevada forma del sense sentit». I és la valoració per parts la que utilitzem per donar diners a la recerca. Com tots sabeu, la valoració per parts consisteix en el fet que un col·lega teu decideix, no la teva excel-lència, no les teves capacitats, sinó la probabilitat que el teu projecte d'investigació pugui arribar a tenir èxit.

No sé si són ràpids o quina mena d'habilitat tenen, però és evident que la capacitat que tenim nosaltres de saber l'èxit que pot tenir una recerca d'un company és pràcticament nul.la. Q uè avalua, doncs, un partner quan tu li presentes una publicació? Avalua la teva credibilitat. Entrem així en el que s'anomena els «cercles de credibilitat». Q uè és el que fa la ciència? Tu aconsegueixes diners si tens diners. Pots publicar articles en revistes prestigioses, si publiques... Si tens diners, pots comprar màquines, pots contractar gent, que és el que permet generar dades, que és el que permet publicar, perquè com tots sabem també, la majoria de les publicacions de prestigi tenen un biaix molt fortament empíric, si no experimental. Per tant, fer experiments, en l'àrea que sigui, costa molts diners. Si tu tens diners, pots contractar persones, pots comprar màquines pots, per tant, publicar, i quan publiques tens credibilitat. I quan tens credibilitat pots obtenir un altre cop diners. Estem doncs en un cicle, i el complicat d'aquest cicle és poder-hi entrar.

I és evident que no s'hi entra al descobert. S'hi entra sempre i quan tu tinguis accés a al gú que ja està dins d'aquest cicle. Perquè has començat publicant amb algú que ja està instal lat en aquest cicle, i això et permet obtenir, una «credibilitat diferida», que alhora et permet després obtenir diners.

Per tant, podríem dir que el que savalua en aquests processos d'avaluació és bàsicament aquesta credibilitat. I per tant, també, el que s'hi avalua és la capacitat de tenir accés a aquesta credibilitat, que, com veiem, no és donada necessàriament per les habilitats d'un mateix 0 , si més no, no només per les habilitats científiques i acadèmiques, sinó per moltes altres consideracions.

Però hi ha un altre factor que a mi, a més a més, m'agradaria comentar aquí i en això jo diria que hi ha poc a dir, és el que fa referència a les línies de 
recerca dominants. Perquè clar, diem, tens diners, pots generar-ne més i això et permetrà accedir a publicar, però també és cert que per publicar, no pots investigar qualsevol cosa. H i ha el que s'anomena «línies d'investigació preferent» que actuen com a «corsé» molt important en el treball de les persones i que fa, també, que aquells que tenen interessos, diguem-ne, desviats tinguin seriosos problemes per publicar en revistes d'impacte, però fins i tot de vegades per publicar directament.

I el que vull donar a entendre és que aquest tema de les línies de recerca dominants és donat o s'agreuja per la seva interacció amb el problema econòmic. I en posaré un exemple que és molt interessant, que està publicat en un llibre de l'editorial Tusquets i escrit per un senyor que es diu Arp, l'obra es titula, més o menys, Controvèrsia sobre distàncies còsmiques i quàsars. Aquest senyor és un investigador important, amb una carrera al darrere important, en l'àrea de la física astronòmica, astronomia..., i té la hipòtesi que la teoria del Big-Bang no és concloent i que hi ha arguments per contradir-la i per demostrar que no és certa.

Però per poder demostrar això, ell necessita fer servir un telescopi, un telescopi important, el H ubble. Evidentment, per fer servir el $\mathrm{H}$ ubble, tu no pots anar allà i dir: «N ecessito mitja hora de H ubble per demostrar que el Big-Bang no existeix», no. $\mathrm{H}$ i ha un comitè, també format per partners que decideix si tu tens dret a utilitzar aquest telescopi. Ja no és un problema que tinguis els diners o no per pagar-ho, és que clar, és tanta la despesa, que hem de considerar si val la pena o no gastar els diners en allò. És evident que el comitè del $\mathrm{H}$ ubble va decidir en el seu moment que aquesta investigació no tenia sentit.

D iguem que està bé que hi hagi un comitè que decideixi el que sembla raonable i el que no ho és per ser investigat, perquè no podem malgastar diners. El que passa és que, com molt bé sabem i sent només popperians, és a dir sense ser anarquistes feyerabenians, sabem que la veritat no es demostra, sinó que, com a molt, demostrem la falsedat de les coses.

El senyor Arp no pot demostrar que el Big-Bang és fals, i tampoc no s'ha demostrat que el Big-Bang sigui veritat. Aleshores, aquest problema I'estic exposant aquí a un nivell, diguem-ne, macro, però es reprodueix constantment i diàriament a les línies editorials de les revistes, que tenen també, dèiem abans, avaluació feta per partners, que no són déus baixats del cel o àngel s asexuats, sinó que tenen línies de recerca clarament determinades. I que estan en aquestes editorials $i$ en aquestes revistes perquè són revistes que també tenen línies editorials clarament determinades, amb la qual arribem a un punt que és greu, ja no és que algunes persones tinguin certs problemes per publicar, perquè segueixen línies de recerca que, diguem-ne, no són les adequades, sinó que el propi ideari de la ciència, que és la recerca del saber pel saber, queda malmès. Perquè certes coses ja no s'investigaran, perquè sabem que certes coses no ens les publicaran. I això fa que els objectius de recerca que es generen entre la comunitat de científics siguin cada cop més pobres, i cada cop més compromesos amb les línies de recerca acceptades, i que cada cop l'originalitat sigui més difícil de manifestar i cada cop estigui més compromesa. 
És a dir, l'avaluació ja no és una qüestió que afecti la meva economia, perquè em donaran més o menys diners si em donen un tram, o més o menys possibilitats d'obtenir diners, sinó que, com a sistema, es o pot arribar a ser un greu obstacle a la mateixa pràctica científica, entesa en el sentit més tradicional del que és la pràctica científica, una recerca del saber pel saber.

Dit ai xò, què s'avalua? Perquè la nostra proposta deia models de recerca alternatius, o propostes al ternatives. Jo no sé què tinc de proposta alternativa, ara a mi se m'acut una cosa..., direu, això és una bajanada, no ho sé, jo estic disposat a fitxar. Si savalua el treball, doncs que savaluiï el treball.

Q uè avaluem? Primerament hem de dir què avaluem, i quan sapiguem què avaluem, sabrem quins són els criteris que podem utilitzar per fer aquesta avaluació. 


\section{Joan Gómez Pallarès}

Com penso que es va dir ahir, jo parlo des de l'àmbit d'humanitats, tot i que si fem servir l'accepció medieval posterior, més aviat potser hauríem de parlar de «itterae humaniores», és a dir, de lletres en el sentit que, des de perspectives en aquest moment potser molt diferents, tots estudiem la repercussió de la persona sobre el medi i com el medi, per quèno, repercuteix sobre la persona, sobre com la persona produeix, i com nosaltres estudiem allò que produeix la persona. I això passa, evidentment, per punts de vista molt diferents, com es podria arribar a posar de manifest si arribéssim al detall. Jo estic molt d'acord amb moltes de les coses que ha dit el professor $\mathrm{C}$ als, i potser amb no tantes, amb algunes també, de les que ha dit el professor $D$ omènech i potser descendiré també una mica al detall.

Fa dos anys i mig, Josep M aria Brucart, antic degà va fer un informe sobre la productivitat científica en el camp de les ciències humanes i socials $\mathrm{i}$ jo no entraré en aquest tema, prou demostrat ja. però no es pot oblidar que jo parlo des de l'àmbit d'humanitats que estudien els textos, la filologia, la filologia clàssica, el llatí i el grec, però els textos EN un context ampli, per tant, m'interessa també molt la civilització on es van produir els textos, m'interessa la història de l'art, m'interessa l'economia de l'antiguitat.

Fa dos anys i mig, en Josep M aria Brucart ja ens va mostrar a tots a bastament, i va destruir el tòpic i el mite que només produeixen, treballen, escriuen i són importants les que fan recerca en ciències experimentals. Tots fem producció, tots tenim la nostra repercussió i, per tant, tots hem de ser tinguts en compte.

Si volia introduir una primera idea abans de parlar de coses més concretes sobre l'avaluació, ha sortit aquí una mica, que és sobre la nostra productivitat. I penso com ha crescut en aquests últims deu anys el nostre campus, en recursos i estructures de recerca i docència en aquestes àrees i conec molt bé com no ha crescut en el nostre camp.

Q uè vull dir? doncs que la nostra productivitat en relació amb allò que rebem, els diners que rebem per fer-ho, és enorme. I els beneficis que en repercuteixen en forma d'infraestructures és mínim, mínim. De què parlaríem en aquests darrers anys? D 'un aulari central, d'una biblioteca d'H umanitats, de la reparació de la biblioteca de $C$ iències Socials. $N$ omés cal que repassem com s'està construint l'edifici d'Enginyeries Q uímiques per veure, com ha dit molt bé el professor $\mathrm{C}$ als, com cal integrar la recerca a la nostra docència, i com cal que fem aquest treball en uns edificis que, com a mínim a la Facultat de Filologia i Lletres, no estan en absolut en les condicions més adequades. Per tant, jo crec que sí que cal fer una reflexió de com repercuteix després en nosaltres l'enorme productivitat en aquesta vessant, sobretot en virtut dels diners que rebem per allò que fem.

Jo crec que en aquests moments ningú no dubta que hem de ser avaluats, aixó ja no es discuteix. El que hem de matisar, efectivament, no són tant els principis del que es fa, sinó la pràctica de com es fa. I per no enganyar ningú, 
i per no enganyar-me a mi mateix, i perquè estic absolutament desconnectat dels documents que es puguin estar refent o proposant en aquests darrers mesos, la meva reflexió s'ha basat en els documents públics que estan disponibles a la xarxa, sigui de la universitat, sigui de la generalitat (CO N ACIT ), etc., documents que tots podeu utilitzar exactament com jo ho he fet. Per tant, és possible que jo introdueixi algun error de detall en puntuacions del CO NACIT, però crec que la reflexió de base, les idees fonamentals que voldria presentar avui continuaran sent igualment vàlides.

Jo crec que sobre els principis bàsics de l'avaluació, el sistema d'avaluació de la recerca en $\mathrm{H}$ umanitats i Ciències Socials, no shi pot dir res. Els principis bàsics són correctes. El que falla és la seva aplicació i el model que la desenvolupa.

El primer que s'ha de fer és posar grups competents en cada una de les possibles matèries avaluables, que sempre estiguin preparats i no intentar, que és el que està succeint ara, que gent amb molta capacitat de treball, però (en el sentit etimològic) no competent en allò que està avaluant, intenti aplicar mecà nicament un document d'avaluació: això porta al fracàs, i a resultats absolutament estrepitosos. Això és el que passa ara, i tots hem tingut alguna experiència de rebre trucades en moments $i$ en hores intempestuoses en què l'interlocutor et demana la teva opinió sobre una cosa que s'avalua en aquells moments. Sense que hi hagi cap comissió d'experts constituïda, senzillament perquè estan intentant aplicar mecànicament un document d'avaluació. N 0 se'n surten perquè hi ha molts aspectes de la nostra producció que no encaixen bé en aquest document que es vol aplicar mecànicament i, per tant, intenten posar-hi pedaços, de qualsevol manera. Això jo crec que és inacceptable, i ja d'entrada invalidaria el sistema d'avaluació que s'està aplicant ara, perquè introdueix una subjectivitat no desitjada. Si hi ha d'haver subjectivitat, criteri i avaluació personal, aquesta ha d'estar molt ben organitzada, molt ben feta i que tothom conegui quines són les regles d'aquesta avaluació. Ara no succeeix això.

I el segon perill que el professor Cals també ha posat de manifest, si més no amb les seves paraules, tot i que potser no l'ha verbalitzat, és el següent: la «producció» pretén ser global, coneguda per tothom, però l'avaluació en aquests moments és terriblement local. És a dir, com he de guiar el que se suposa que és la meva producció científica, perquè el que se'n demana en aquests moments és que condicionem aquesta producció al sistema com serà avaluada aquesta producció? Segons el criteri de la UAB? que és un. Segons el criteri de la U PF? Si potser resulta que jo conec que un dels avaluadors de la CO N ACIT és de la U PF, segons el criteri C O N ACIT? Segons el criteri de M adrid? Segons el criteri que estan preparant a la U niversitat de Sevilla? És absolutament impossible en aquests moments saber qui i com exactament ens avaluaran, i a través de quins criteris es farà. El professor C als ha manifestat, i ho sabem tots, que oficiosament circulen llistes, que si aquest professor ve de la U AB i avalua a M adrid o li porten un paper a M adrid traurà un Ilistat de la $U A B$, que si... Això és impossible, no es pot acceptar un sistema així. Com a mínim, a nivell d'Espanya o de C atal unya, hi hauria d'haver un únic sistema conegut per tothom, accep- 
tat per tothom, debatut per tothom. I això en aquests moments no existeix. Al contrari, el que s'està potenciant és un sistema d'avaluació basat en criteris locals que, de fet, perjudical'avaluació d'una producció que es pretén, en aquest sentit, que sigui de repercussió global.

Sobre l'esquema de l'avaluació i la seva aplicació, jo crec que és un sistema que, al marge de les puntuacions i de valoracions (de les quals també en parlaré una mica, com a mínim des del meu àmbit), recull totes les activitats importants. Fins $i$ tot les activitats científiques de recerca que nosaltres fem des del nostre àmbit: el problema és com es valoren aquestes activitats.

El bloc $A$, que és el bloc rendible, el bloc de publicacions que s'endú entre el 60 i el $70 \%$ de les valoracions, està absolutament decantat cap a la producció científica de l'àmbit de ciències experimentals i biomèdiques, on és, com vosaltres sabeu perfectament, molt més difícil que una investigació important es publiqui en un llibre que no pas en un article, exactament el contrari del que passa en molts dels àmbits de les ciències humanes $i$ socials.

Jo crec que no és admissible, en aquest marc, que un article del grup A, i perdoneu que faci servir termes com aquest, valgui el mateix que el millor llibre - la millor edició crítica de text. I per dir-ho molt breument, segons la llista de les revistes de filologia, un article meu, a una revista del grup A, i estic parlant de l'últim cas que m'ha costat sis mesos de feina intensa, sis mesos de feina, valdrà el mateix, valdrà exactament el mateix, que la meva millor edició crítica de textos. La progressió general del coneixement en filologia se centra a llegir, editar, conèixer i comentar els textos clàssics grecollatins millor, o intentar-ho, del que ho havien fet les generacions anteriors. I sempre hem progressat de la mateixa manera des dels filoolegs al exandrins. Aquesta millor edició meva, aquesta millor edició crítica meva, que m'ha obligat a revisar vint-i-quatre manuscrits a set països diferents, cinc anys de feina, valdrà exactament el mateix queel millor article que m'ha costat sis mesos, del grup A, exactament el mateix.

Encara us donaré una altra dada, Iligada amb la recerca i a la manera com ens arriben els diners, i en això discreparia una mica del que deia el professor D omènech. El millor llibre que jo aspiro a publicar, i en el qual estic trebaIlant, jo i tot el meu equip de deu persones de quatre universitats espanyoles, el millor llibre que aspiro a publicar, que ha rebut i que té suport com a grup de recerca de la G eneral itat, grups de recerca de qualitat (SGR), de diferents projectes del M inisteri i que té una distinció de la G eneralitat. És a dir, no estic parlant de cap bestiesa en l'àmbit de les ciències humanes, estic parlant de més de trenta milions de pessetes, i que acabarà com a projecte i com a un únic llibre, això sí, publicat en la millor editorial. Tampoc no entraré en detall de com sidentifiquen, savaluen i es defineixen les editorials en aquest document, que sortirà el 2004 i que ha rebut més de trenta milions de finançament públic per poder ser executat, valdrà exactament el mateix que aquest article meu a la revista de més impacte a la revista $A$. Això és absolutament inadmissible des de l'àmbit de les ciències humanes que jo represento avui en aquesta mesa.

Jo crec que l'aplicació habitual d'aquest sistema no és sostenible ni defensable, perquè, com ha dit el professor Cals, crea avaluacions distorsionades, i si 
no vols una avaluació distorsionada, has d'adaptar, i aquesta és la més terrible paradoxa i jo diria la pitjor crítica que es pot fer a aquest sistema d'avaluació, has d'adaptar el teu treball científic a allò que s'avaluarà algun dia, quan s'ha demostrat, com a mínim en el meu camp, que la manera de treballar bàsica que us intento descriure avui és bona i funciona. Si jo vull rebre més diners 0 continuar treballant amb un reconeixement públic, he de modificar la meva pauta de treball. Per tant, us deia que en aquest sentit no és ni defensable ni sostenible, aplicable sí, perquè es fa.

Jo crec que no ho és sobretot en el punt on el professor $C$ als ha fet més èmfasi, i jo també volia parlar una mica dels meus exemples i dels problemes que hi veig. I fer, o almenys tenir l'atreviment d'intentar fer una proposta final, en l'àmbit de les revistes, de les Ilistes de revistes que és el seu punt cabdal. El punt cabdal de l'avaluació de la recerca tal com estan considerats en aquests moments, perquè és el que aporta més puntuació.

El concepte que tenen a l'actual estructura jerarquitzada de revistes, crec que és insostenible. I només parlaré de les meves. El professor $C$ als n'ha fet una crítica sistemàtica, tot i que no ens I'ha introduïda tota, mentre que jo faré una crítica sistemàtica per defensar la idea que s'ha d'eliminar, aquella llista de revistes tenint com a premissa molt clara, com a mínim jo, espero que tothom, que evidentment hem de continuar sent avaluats, però no d'aquesta manera.

Com deia el professor $D$ omènech, hi ha una primera contradicció que és, que si el que és important és la qualitat i no la quantitat, el que importa evidentment és què s'escriu i no on s'escriu. Per tant, jo crec que la millor manera possible d'avaluar seria construir entre tots un índex de repercussió, ja ho diu la idea d'índex, de citacions per impacte. Un índex de repercussió en huma nitats que no existeix, en ciències socials teniu alguns instruments. Jo crec, i per això sap més greu encara, que els responsables polítics avui haurien de ser aquí (encara), en aquesta universitat, perquè crec que hauria de ser una preocupació fonamental seva. I a nivell de la G eneralitat, com a mínim, caldria construir aquest índex que tingués repercussió en revistes d'humanitats.

No em serveix que algú em digui que podríem referir-nos a Tocs In, per exemple, per dir que en humanitats ja tenim un índex d'impacte, un índex de repercussió. No em serveix, perquè són eines de treball molt valuoses, però bàsicament el $90 \%$ d'aquestes publicacions (més amunt ja hasortit) està centrat en els àmbits anglosaxó i germànic. Per tant, les revistes molt bones i valuoses en el meu àmbit publicades a Espanya, a Itàlia, a França... i, també alguna de molt important del nord d'Àfrica, no tenen cap repercussió en un índex informàtic com el de Tocs In. Llavors, si no hi ha un índex de repercussió, hi ha d'haver algun tipus de jerarquització, penso que potser sí, però amb molts matisos, i, en qualsevol cas, no com s'ha fet fins ara.

Per intentar argumentar i demostrar que la llista, pel que fa a filologia, com ha demostrat en l'àmbit d'economia el professor $C$ als (i és la llista de revistes on es basa, la pedra angular de l'avaluació), és insostenible i no es pot defensar, us en posaré alguns exemples breus només del meu camp. 
Al grup A, com ja s'ha dit abans, no hi ha ni una sola revista editada en àmbit no anglosaxó o germànic. I en ciències humanes i en filologia, suposo que això passa a tot arreu, però només puc parlar dels meu àmbits, els lobbies científics, els grups de pressió, funcionen i funcionen molt bé. Abans ha apuntat el professor D omènech l'exemple del H ubble i en això sí que pot passar que tu no tinguis accés a un grup $A$, no per qualitat o per manca de qualitat, sinó perquè no pertanys al grup $X$ o al grup $Z$. 0 perquè allò que publiques no els interessa, perquè argumenta en contra d'allò que ells pensen, i de fet actuen en contra de propiciar el debat científic, perquè no inclouen en la pròpia revista pensaments amb els quals no estan d'acord.

En canvi al grup $C$, seguint una mica amb el que deia el professor $C$ als, hi ha revistes que segueixen estrictament els criteris d'objectivitat, lectura anònima, etc., que es demanen per al grup A i són al grup C, això sí, són publicades a França, són publicades a Itàlia, i són publicades a Espanya.

Si em diguéssiu: sí, sí, però tot això ho estàs dient perquè tu no publiques al grup A o al grup B, m'és igual ara intentar demostrar si serveix o no per publicar en aquestes revistes perquè, em sembla que no hi ha ningú en aquesta sala que m'hagi d'avaluar en un futur, 0 en aquesta taula, com a mínim que sigui del meu àmbit, de filologia. Però és que fins i tot aquestes revistes del grup A i del grup B són insostenibles, perquè s'hauria de ser molt estricte en la inclusió en aquests dos grups, i no se n'és gens, d'estricte.

Els criteris de qualitat pels quals han estat triades aquestes revistes, no són respectats per les pròpies revistes. N o vull fer ara com aquell professor, el nom del qual no recordo, de ciències de l'educació que va enviar tres o quatre «submarins» en alguns congressos de la seva especialitat, no vull fer això, però sí que parlaré de la meva experiència. Jo us puc assegurar que he publicat (us ho puc assegurar perquè en tinc les proves), els darrers cinc anys, no diré en quines revistes, ni quins articles (per allò que potser algun dia al gú que ara és aquí hagi de mirar el meu currículum), jo he publicat en els darrers cinc anys tres articles, tres articles en dues revistes del grup A i en una revista del grup B que no han rebut cap mena d'avaluació, ni de lectura anònima ni de crítica a aquell article rebuda per mi, pel lector anònim, ni resposta meva a aquesta crítica del lector 0 dels dos avaluadors anònims. Tres articles en cinc anys, tres per vuit, vint-i-quatre punts. Vint-i-quatre punts rebuts, sense cap mena d'avaluació seguint els criteris de les revistes del grup A, que demostren com el sistema no funciona perquè les revistes no funcionen com ens pensem que han de funcionar. Tres articles que jo he enviat a la revista, i com que resulta que el director 0 al gú del consell de redacció em coneix, m'escriu una carta immediatament al cap de quinze dies i em diu: «N o pateixis, aquest article es publicarà», i s'ha acabat el bròquil. Si sistema d'inclusió de revistes al grup A i B funcionés estrictament, mél podria creure i podria arribar a pensar que aquesta avaluació pot ser objectiva algun dia. Però ara, per la meva experiència personal, no me'l crec i, per tant, no em serveix ni vull que em sigui aplicat, perquè us demostro que aquestes revistes no segueixen els criteris pels quals han estat incloses en la llista i al grup primer. 
Algunes altres perles, poques, com ja ha dit el professor $\mathrm{C}$ als, una de les tres millors revistes que es publiquen sobre l'edat mitjana en general, tant si es tracta de textos escrits en llatí, com també en llengües vul gars, en qual sevol de les llengües dites «vulgars», és al grup C, i segueix estrictament tots els criteris pels quals hauria de ser al grup A. Això, és producte de la pressió dels lobbies? És producte de la mala fe de les persones que han fet les Ilistes de la CONACIT aquí? No! Es producte, i permeteu-me que ho digui així, etimològicament, és producte de la ignorància de les persones que ho han fet. Però no hi ha com reconèixer la pròpia ignorància per poder-se corregir. I no s'està en aquest camí tampoc. I mireu que és fàcil: com que no ho sé tot, no ho puc saber tot, busco bons experts, exposo al guna teoria que sigui defensable, aplicable per tothom. D oncs aquestes revistes no hi són. Al grup B hi ha una de les revistes més arbitràries i de menys difusió en filologia clássica que existeix: Analecta M alacitana, jo m'estimo M àlaga, m'estimo la U niversitat de $M$ àlaga, hi tinc molts col-leguesi bons amics, però, és clar, en ma vida se m'hauria acudit, si vull que algú em Ilegeixi, publicar a Analecta M alacitana. Però quan vaig veure la llista i em vaig adonar que estava al grup B, em va faltar temps per publicar un article en aquesta revista, i ara n'hi tinc dos, però, és clar, ja sé que no tindran gaire sortida. I l'altra cosa és que, si fem una llista de característiques semblants, l'hauríem de revisar periòdicament, com a mínim cada sis mesos.

En l'àmbit d'humanitats proliferen molt les revistes publicades exclusivament a Internet. Clar, com que els motors de recerca a Internet, perquè per molt que vosaltres us penseu que jo em dedico al llatí, és un dels àmbits on s'aplica més, millor la informàtica. Com que els motors de recerca més especialitzats tre ballen molt bé en els àmbits de ciències humanes, en ciències de l'antiguitat, si jo publico a l'Anal ecta $M$ alacitana electrònica, ja sé que qualsevol persona que busqui un article meu l'hi trobarà, perquè els controls de recerca de l'antiguitat funcionen molt bé a la xarxa. Clar, dos articles a Analecta M alacitana. Jo potser no hi hauria publicat mai. Però està el proper, algú ha decidit que fos el proper, i aquí sí que hi ha el tema delobbiesi d'interessos de debò: És clar que qui ha fet la llista mira el seu currículum i hi posa alguna de les revistes on ell ha publicat. D oncs ha funcionat així la confecció de la llista.

Al grup C, repeteixo, hi ha revistes rigoroses que haurien de ser al grup A 0 al grup B a molt estirar. Alguns dels disbarats més grans són, per exemple, en citaré només dos: la millor revista (no publica estrictament allò que en podríem dir «nvestigació». N o publica estrictament articles de recerca d'investigació bàsica, però és la millor revista del món en revisió de bibliografia crítica i en aportació de dades de bibliografia, està publicada per l'Associació de Filòlegs C làssics de la Gran Bretanya, a 0 xford), és al grup D ! I parlant de les absències, també vull citar un altre exemple. La millor revista del món en l'estudi de l'escriptura i dels seus suports, la millor revista d'història del text de transmissió de manuscrits, la millor revista del món, sigui en llatí ,en grec 0 en vulgar, no hi és al repertori. $\mathrm{Ni}$ al grup $\mathrm{A}$, ni al $\mathrm{B}, \mathrm{ni}$ al $\mathrm{C}$ ni al $\mathrm{D}$, es tracta de la Revue d'histoi re des textes, publicada a París, no hi és. 
Com vosaltres comprendreu, jo vull ser avaluat, jo crec que és molt important, i això és el que ens ha donat credibilitat a les ciències humanes i socials davant els nostres companys de campus en els darrers anys. Jo vull ser avaluat, però jo vull ser ben avaluat.

H e tingut molta sort, per què? Perquè un sistema, com hem vist, arbitrari, un sistema personalista, m'ha permès, efectivament, continuar treballant, però si volem ser avaluatsi «recompensats», per això, el que no podem fer és caure en la paradoxa de dir: «ara que vull ser més objectiu, ara et perjudicaré més». $\mathrm{H}$ a de ser exactament el contrari, ara que volem ser més objectius, fem-ho bé. I, en canvi, ara que volem ser més objectius, ho fem cada vegada pitjor.

Acabaré fent una petita proposta sobre com podem solucionar això en la publicació en revistes, l'altre aspecte ja he dit com es podia solucionar: donant molta més importància en punts, perquè es el sistema que fem servir a les publicacions que respecten el nostre sistema de treball en ciències humanes, llibres, capítols de llibres.

Pel que fa a revistes, jo proposaria eliminar aquesta llista. $\mathrm{H}$ em demostrat a bastament (i tots els que són en aquesta taula, en el seu àmbit, podrien fer el mateix en la llista que utilitzen) que aquest sistema no funciona.

Jo proposaria, per a cada àmbit científic (que ara no voldria delimitar ni definir, perquè tindríem una discussió que potser avui no toca), crear una comissió d'experts en totes les matèries avaluables. Una comissió que sempre estigués preparada per actuar, després d'haver fet la feina inicial que us donaré ara, que acredités les revistes. És a dir, a mi m'és igual, com a filòleg clàssic, que la revista es publiqui a $\mathrm{M}$ adrid, a 0 xford, 0 on sigui. El que vull és que tingui els criteris rigorosos d'admissió d'originals, de selecció d'originals i de neutralitat en l'admissió d'originals. I, per tant, hi hauria d'haver una comissió d'experts que, en cada àmbit, acredités i seleccionés les revistes, sense puntuacions, sense barems, sense jerarquia. Totes aquelles revistes que seran tingudes en compte per a una futura valoració científica seran aquestes. I aquesta base de dades, aquesta llista, que sigui revisada cada tres mesos. Si fas un comitè, fas una selecció, li pagues uns diners, perquè, naturalment, de mèrits n'hi ha d'haver i en el proper pla de recerca de la $G$ eneralitat hi ha diners, mil milions més cada any, des del moment en que ha estat aprovat. Fem-ho bé. I construïm, en ciències huma nes, perquè en ciències socials ja tenim alguns instruments disponibles a la xarxa i en CD per avaluar, construïm, deia, un índex de repercussió de la nostra feina a partir d'aquesta nova llista de revistes, i punt. C om més repercussió tingui la teva feina, si ha estat ben avaluada i seleccionada per revistes homologades, més amunt serà la teva tasca científica en l'escala de valoració. Sigui la que sigui, sigui una edició d'un Ilibre, si el llibre en ciències de l'antiguitat i filologia clàssica i en el món anglès i en el món americà, l'edició de llibres és una feina cabdal! Edició vull dir en el sentit anglosaxó. Tu tens una hipòtesi de treball, tens una idea, tries set persones, cadascuna te n'escriuen un capítol i acabes donant una nova visió d'un aspecte, el que sigui.

Si tu tens un equip de gent que homologa els textos, a partir d'aquí, la repercussió, tant si estan publicats en revista, com en capítol de llibre, com en 
Ilibre, existirà. I serà i ha de ser mesurable i avaluable. I això és el que no tenim en ciències humanes.

El que jo proposaria és, doncs, eliminar aquesta absurda llista jerarquitzada de revistes $i$ fer una cosa d'aquest estil. La resta d'activitats científiques per les quals som avaluats, ja he dit abans, crec que hi són totes les importants, 0 gairebé totes, tot i que en ciències humanes - i ara no entraré en aquest debates podrien fer altres matisos sobre com puntuen o què puntuen, però com que sempre hi ha una petita forquilla de puntuació, de més a menys, sempre hi ha d'haver un comitè d'experts preparat per avaluar els temes. I fugim també, si apliquem aquest nou sistema, d'allò de rebre una trucada a la tarda on ens diguin: «Ei, que t'envio un fax perquè m'avaluïs aquestes quatre publicacions». $\mathrm{H}$ em de fugir d'això per sempre més. 